\title{
Reconstruction of the Late Pleistocene to Late Holocene vegetation transition using packrat midden and pollen evidence from the Central Mojave Desert
}

\author{
Behnaz Balmaki* (D) and Peter E. Wigand ${ }^{2}$ (])
}

Received: April 28, 2019

Accepted: June 28, 2019

\begin{abstract}
The Mojave Desert of the American West is characterized by plant species that reflect a unique mixture of winter precipitation and summer monsoon climate. Currently, the Mojave Desert experiences a strong summer monsoonal pattern with weak winter precipitation. Data from pollen and packrat midden analyses have revealed a history of Mojave Desert vegetation during the transition from the late Pleistocene to late Holocene ( 17500 Cal. years B.P. to 1200 Cal. years B.P.) that highlight a summer dominated monsoonal pattern, similar to those in the greater American Southwest. We compare pollen data from a lava tube in the Cima volcanic field, located in south-central region of the Mojave Desert, with plant macrofossil data from several woodrat midden localities in the region. The record for the Cima volcanic field reveals a vegetation history spanning the last $~ 8300$ Cal. years B.P., with data from ancient woodrat middens detailing the record from $17500 \mathrm{Cal}$. years B.P. to 7,800 Cal. years B.P. A Bryson macro-physical climate model for the transition from the late Pleistocene to the Late Holocene was created and compared to our findings to assess possible relationships between climatic variations and the arrival of diagnostic plant species within the Mojave Desert.
\end{abstract}

Keywords: Late Pleistocene, Late Holocene, Mojave Desert, pollen, summer monsoon, woodrat midden analysis

\section{Introduction}

The transition from the Pleistocene to Holocene (LP/H) resulted in significant climate-driven change within Mojave Desert plant communities. Plant species exhibited both geographic expansion from the Sonoran Desert and more localized elevational shifts establishing modern vegetation zones. Packrat middens and sediment pollen analyses are some of the most reliable proxies to recreate vegetation history and past climate (Cole 1985). Packrat middens often contain abundant pollen and plant microfossils, encased in crystalized woodrat urine (Cole 1985). A pollen record obtained from sediment within a lava tube of the Cima volcanic field enabled a reconstruction of early Holocene vegetation communities at low elevation. The $\mathrm{LP} / \mathrm{H}$ transition in southern California (Quade et al 1998; Wigand $\&$ Rhode 2002) was quite dramatic east of the Sierra Nevada.

Spaulding (1985) and Koehler et al. (2005) indicate that the key elements of Mojave Desert vegetation arrived by 9,500 Cal. years B.P. Creosote bush and white bursage are considered co-dominants, though Wigand's (2003) research just south of the Coso Range at the northwestern edge of the Mojave Desert indicates that with increased winter

1 Department of Geological Sciences \& Engineering, University of Nevada, Reno, 89557, Reno, NV, USA

2 Department of Geology, California State University, Bakersfield, 93311, Bakersfield, CA, USA

* Corresponding author: B.balmaki@Nevada.unr.edu 
precipitation, white bursage is favored. Conversely during years exhibiting increased summer precipitation, creosote bush is favored.

Climate at the end of the Pleistocene probably favored white bursage, because periods of increased winter precipitation may still have been common. The impact of climate change on landscape dynamics at the end of the Pleistocene has been previously discussed by Harvey et al. (1999). The authors indicate that alluvial fans in the Mojave Desert during the LP/H transition was very active, exhibiting debris flows feeding onto the fan surfaces, headward fan trenching, and distal progradation. Increased geomorphology activity in the Mojave Desert during the LP/H may have been due primarily to decreased vegetation cover. The replacement of Pygmy juniper and sagebrush at the end of the Pleistocene by creosote bush and white bursage led to a more open discontinuous vegetation cover in the Mojave Desert. Schumm's model (Langbein \& Schumm 1958) indicates drier conditions result in reduced vegetation density. When reduced vegetation cover coincided with episodes of high-intensity summer rains, it resulted in increased hillslope debris flow activity in the Mojave Desert. Fine sediments eventually filled the pluvial basins of the region, and as the basins dried up. the fine particles were transported as aeolian sediments onto the Cima volcanic field. In this research, we examine late Quaternary Mojave Desert vegetation history, derived from pollen and packrat midden proxies, to reveal the timing and order of arrival of diagnostic species into the region.

\section{Materials and methods}

\section{Study area}

The Mojave Desert lies between the summer monsoondominated Sonoran Desert to the southeast and the zonal, winter storm-dominated Great Basin Desert to the northwest. It therefore exhibits a combination of the climates of two regions resulting in a fluctuating summer monsoonal pattern originating from the southeast Mojave Desert. Generally, the Mojave Desert is characterized by three climatically distinct regions. These include: a) the western region dominated by cool winters and warm summers; b) the central region, which has generally warmer winters than the eastern and western regions and hot summers; and c) the eastern region, which has cooler and wetter winters with greater precipitation (McKinney 2018).

The Cima volcanic field is located southwest of Las Vegas, Nevada (Fig. 1), and consists of roughly 60 associated lava flows and 40 cinder cones of Pleistocene age covering 150 $\mathrm{km}^{2}$ of the Ivanpah uplift (Dohrenwend et al. 1984; Turrin et al. 1985; Wilshire et al. 1987; Wood et al. 2005). PotassiumArgon (K-Ar) dating of cinder cones within the Cima volcanic field provide an age range of $0.015 \mathrm{~m}$ yr to $1.09 \pm 0.08 \mathrm{~m}$ yr (Dohrenwend et al. 1986). The lava flows are mostly alkali olivine basalt, hawaiite and basanite, and occur in two flow types, 1) elongate flows with low gradients, and 2) roughly equant flows (of similar length and width) with high gradients (Dohrenwend et al. 1984).

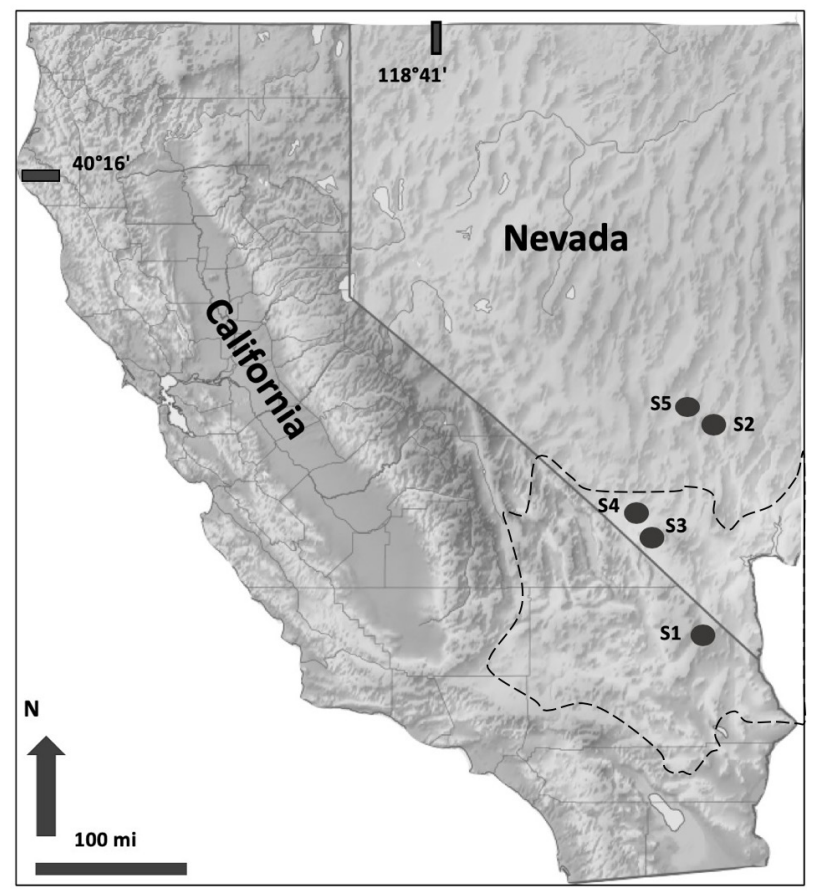

Figure 1. Map of the Mojave Desert, Southern Nevada and California, and sites discussed in this text: S1: Cima volcanic field, S2: Pahranagat Range, S3: Owl Canyon, Devils Hole Range, S4: Little Skull Mountain, Nevada test site, S5: Timpahute Range

The mean annual precipitation of Cima volcanic field is well within the range for arid to semiarid zones, at 12-25 $\mathrm{cm}$ and the plant community of the Cima volcanic field is dominated by creosote bush (Larrea tridentata), white bursage (Ambrosia dumosa), brittle bush (Encelia farinosa) and Mormon tea (Ephedra trifurca) though higher elevations (> 1300 masl) contain Joshua tree (Yucca brevifolia) (Brown et al. 1990).

\section{Pollen sampling}

Six sediment samples were collected in 2012 from sediments inside one of the Cima lava tubes. Pollen was recovered using sodium polytungstate flotation (Wigand 1987). The processed samples were stained and mounted in silicon oil before being counted at 400 power with a light microscope.

\section{Packrat middens}

Plant macrofossils from 18 packrat middens from near the Nevada Test Site were analyzed during this study. The middens were mapped, described, photographed and subsamples taken over a period of several years. Samples 
were soaked in distilled water for 24 hours, screened through nested screens, and dried. The resultant macrofossil material was then sorted and weighed and entered into a database.

\section{Chronology}

Twenty plant macrofossil and organic-rich sediment samples were dated by Beta Analytic Inc, Miami, Florida using accelerator mass spectrometry (AMS). The dates were calibrated using IntCal13 curve 133 (Reimer et al. 2013).

\section{Paleoclimate Simulation}

A Bryson MCM synoptic climate model simulation was generated for the central Mojave Desert highlighting the last 15,000 years. The simulation was based on 30 year means from the Las Vegas, Nevada, climate means of 1971 to 2000 (Bryson \& Bryson 2000) and compares correlations between predicted climatic variation and our reconstructed vegetation histories.

\section{Results}

\section{Chronology}

AMS dating results are presented in Tables 1 and 2. The three sediment samples from the Cima volcanic field span the last 8,300 Cal. years B.P. Middens ages ranged between $7,853 \pm 119$ Cal. years B.P. to $17,480 \pm 282$ Cal. years B.P., covering the entire LP/H transition (Tab. 2).

\section{Pollen assemblages}

Ten pollen types were identified, and their abundance analyzed within the Cima volcanic field samples (Fig 2).
Pinus (pine) (1.75\%) and Eriogonum (buckwheat) (10.53\%) were exclusive to the upper portion of the sample trench (younger than $2510 \mathrm{Cal}$. years B.P.). Artemisia was also only found in the upper portion of the trench where it ranged from 1.22 to $2.63 \%$. Ambrosia pollen is one of the most common pollen types throughout the core, but its abundance was greatest (95\%) at $~ 8300 \mathrm{Cal}$. years B.P. Spharaelcea was found throughout the middle and upper portion of the trench, ranging between 5.26 to $42.11 \%$, but not in the lower portion at all.

Table 1. $A M S{ }^{14} \mathrm{C}$ dates for sediment sample in Cima volcanic site

\begin{tabular}{|c|c|c|c|}
\hline Sample & Depth $(\mathbf{c m})$ & 14C (yr.BP) & 14C (cal. yr.BP) \\
\hline CV-30 & 30 & 2400 & 2510 \\
\hline CV-90 & 95 & 3500 & 3785 \\
\hline CV-135 & 135 & 7500 & 8300 \\
\hline
\end{tabular}

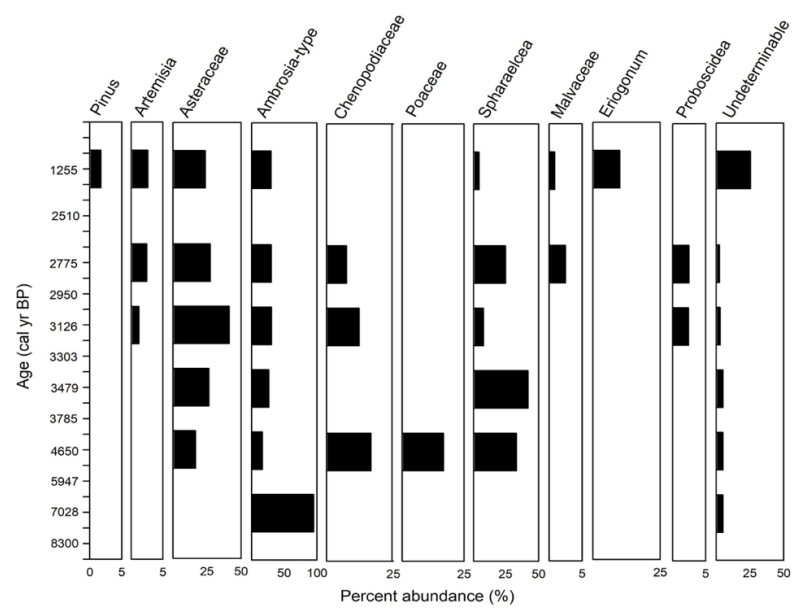

Figure 2. The relative abundance (\%) and concentration of pollen for Cima volcanic field.

Table 2. Site location and radiocarbon dates from central Mojave Desert packrat middens.

\begin{tabular}{|c|c|c|c|c|c|c|c|c|}
\hline Sample & Location & Lab code & Elevation $(\mathrm{m})$ & Latitude & Longitude & $14 C(y r B P)$ & 14C (cal yr BP) & Material \\
\hline MJ1 & Pahranagat Range & Beta28467 & 1600 & $37^{\circ} 22^{\prime} 40^{\prime \prime} \mathrm{N}$ & $115^{\circ} 18^{\prime} 1 ” W$ & $7,030 \pm 130$ & $7,853 \pm 119$ & dung \\
\hline MJ2 & Owl Canyon, Devils Hole Range & Beta- 64330 & 790 & $36^{\circ} 23^{\prime} 54^{\prime \prime} \mathrm{N}$ & $116^{\circ} 14^{\prime} 26^{\prime \prime} \mathrm{W}$ & $8,180 \pm 60$ & $9,150 \pm 92$ & twigs \\
\hline MJ3 & Little Skull Mountain, Nevada test site & Beta26581 & 1150 & $36^{\circ} 43^{\prime} 43^{\prime \prime} \mathrm{N}$ & $116^{\circ} 19^{\prime} 36^{\prime \prime} \mathrm{W}$ & $8,480 \pm 130$ & $9,454 \pm 136$ & dung \\
\hline MJ4 & Pahranagat Range & Beta31328 & 1600 & $37^{\circ} 22^{\prime} 40^{\prime \prime} \mathrm{N}$ & $115^{\circ} 18^{\prime} 1^{\prime \prime} \mathrm{W}$ & $9,120 \pm 110$ & $10,328 \pm 125$ & dung \\
\hline MJ5 & Pahranagat Range & Beta-86072 & 1715 & $37^{\circ} 22^{\prime} 25^{\prime \prime} \mathrm{N}$ & $115^{\circ} 17^{\prime} 15^{\prime \prime} \mathrm{W}$ & $9,230 \pm 50$ & $10,397 \pm 85$ & piñon \\
\hline MJ6 & Owl Canyon, Devils Hole Range & Beta34790 & 790 & $36^{\circ} 23^{\prime} 54^{\prime \prime} \mathrm{N}$ & $116^{\circ} 14^{\prime} 26^{\prime \prime} \mathrm{W}$ & $9,420 \pm 130$ & $10,742 \pm 240$ & dung \\
\hline MJ7 & Little Skull Mountain, Nevada test site & Beta 26011 & 1150 & $36^{\circ} 43^{\prime} 43^{\prime \prime} \mathrm{N}$ & $116^{\circ} 19^{\prime} 36^{\prime \prime} \mathrm{W}$ & $9,480 \pm 370$ & $10,830 \pm 516$ & dung \\
\hline MJ8 & Timpaute Range & Beta 25683 & 1780 & $37^{\circ} 34^{\prime} 31^{\prime \prime} \mathrm{N}$ & $115^{\circ} 39^{\prime} 40^{\prime \prime} \mathrm{W}$ & $10,040 \pm 130$ & $11,634 \pm 261$ & juniper \\
\hline MJ9 & Little Skull Mountain, Nevada test site & Beta 25675 & 1150 & $36^{\circ} 43^{\prime} 43^{\prime \prime} \mathrm{N}$ & $116^{\circ} 19^{\prime} 36^{\prime \prime} \mathrm{W}$ & $10,460 \pm 140$ & $12,340 \pm 240$ & dung \\
\hline MJ10 & Pahranagat Range & Beta 32402 & 1600 & $37^{\circ} 22^{\prime} 40^{\prime \prime} \mathrm{N}$ & $115^{\circ} 18^{\prime} 1^{\prime \prime} \mathrm{W}$ & $11,710 \pm 150$ & $13,600 \pm 193$ & juniper \\
\hline MJ11 & Little Skull Mountain, Nevada test site & Beta25676 & 1150 & $36^{\circ} 43^{\prime} 43^{\prime \prime} \mathrm{N}$ & $116^{\circ} 19^{\prime} 36^{\prime \prime} \mathrm{W}$ & $11,970 \pm 110$ & $13,950 \pm 240$ & juniper \\
\hline MJ12 & Pahranagat Range & Beta31322 & 1600 & $37^{\circ} 22^{\prime} 40^{\prime \prime} \mathrm{N}$ & $115^{\circ} 18^{\prime} 1 ” W$ & $12,120 \pm 90$ & $14,150 \pm 259$ & dung \\
\hline MJ13 & Pahranagat Range & Beta-74776 & 1695 & $37^{\circ} 22^{\prime} 25^{\prime \prime} \mathrm{N}$ & $115^{\circ} 17^{\prime} 13^{\prime \prime} \mathrm{W}$ & $12,280 \pm 60$ & $14,394 \pm 306$ & fir \\
\hline MJ14 & Owl Canyon, Devils Hole Range & Beta32398 & 812 & $36^{\circ} 23^{\prime} 54^{\prime \prime} \mathrm{N}$ & $116^{\circ} 14^{\prime} 26^{\prime \prime} \mathrm{W}$ & $12,260 \pm 110$ & $14396 \pm 342$ & dung \\
\hline MJ15 & Owl Canyon, Devils Hole Range & Beta-86041 & 812 & $36^{\circ} 23^{\prime} 54^{\prime \prime} \mathrm{N}$ & $116^{\circ} 14^{\prime} 26^{\prime \prime} \mathrm{W}$ & $13,540 \pm 60$ & $16,521 \pm 380$ & juniper \\
\hline MJ16 & Pahranagat Range & Beta34792 & 1600 & $37^{\circ} 22^{\prime} 40^{\prime \prime} \mathrm{N}$ & $115^{\circ} 18^{\prime} 1^{\prime \prime} \mathrm{W}$ & $13,470 \pm 200$ & $16,363 \pm 479$ & juniper \\
\hline MJ17 & Little Skull Mountain, Nevada test site & Beta 25679 & 1150 & $36^{\circ} 43^{\prime} 43^{\prime \prime} \mathrm{N}$ & $116^{\circ} 19^{\prime} 36^{\prime \prime} \mathrm{W}$ & $13,740 \pm 130$ & $16,841 \pm 255$ & juniper \\
\hline MJ18 & Little Skull Mountain, Nevada test site & Beta 25677 & 1150 & $36^{\circ} 43^{\prime} 43^{\prime \prime} \mathrm{N}$ & $116^{\circ} 19^{\prime} 36^{\prime \prime} \mathrm{W}$ & $14,280 \pm 180$ & $17,480 \pm 282$ & yucca \\
\hline
\end{tabular}




\section{Packrat middens}

Table 3 gives dates for the expected arrival of major plant components of the Mojave Desert (Fig. 3).Most macrofossil materials came from shrubs including: Artemisia tridentate (big sagebrush), Purshia tridentate (bitterbrush), Symphoricarpos longiflorus (snowberry), Prunus fasciculata (desert apricot), Salvia dorrii (purple sage), Tetradymia glabrata, (smooth horsebrush) Ephedra sp. (Mormon tea), Atriplex canescens (four-wing saltbush), Atriplex confertifolia (shadscale), and Larrea tridentate (creosote bush). Macrofossils of grasses, (e.g., Stipa hymenoides) Yucca brevifolia (Joshua Tree), Cactaceae (cactus) and some trees, including Pinus flexilis (limber pine), Abies concolor (white fir), Juniperus osteosperma (Utah juniper), Pinus monophyla (piñon pine) and Celtis reticulata (hackberry) were also recovered. All plant macrofossils are from woodrat middens found at elevations between 790 to $1710 \mathrm{~m}$ (i.e. from the top of the bajadas to middle elevations in the mountain ranges). Some elements appear much earlier than previously reported (e.g., Yucca brevifolia (Joshua Tree)). One component, Larrea Tridentata does not appear until 9,500 Cal. years B.P.

\section{Paleoclimate simulation}

The MCM climate reconstruction reveals that summer precipitation within the Mojave Desert during the LP/H has the great variability, followed by that of spring precipitation. Fall and winter precipitation were much less variable., though during the LP/H both fall and spring precipitation have episodes of high variability that correspond to those periods when summer precipitation exhibits its highest variability. As will be discussed below, episodes of highest frequency and magnitude in summer precipitation are crucial to the appearance of characteristic Mojave Desert plant species.

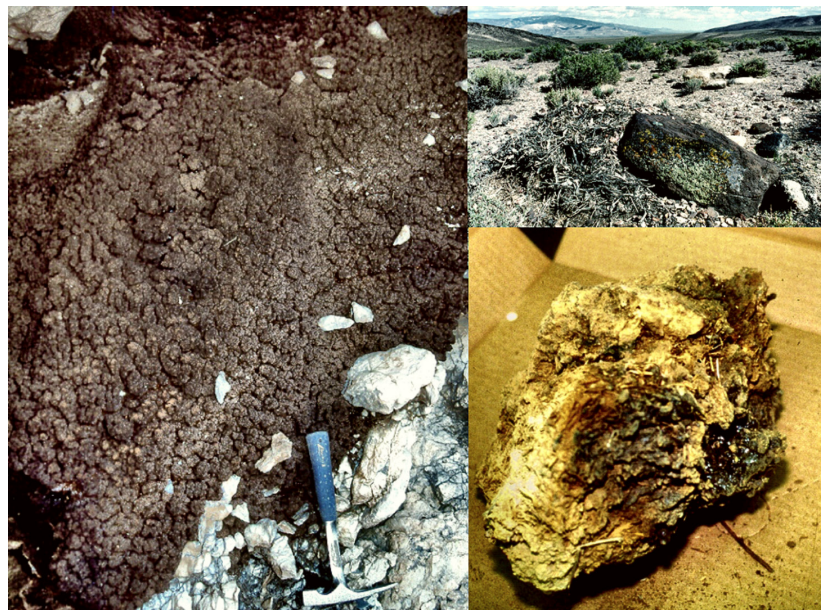

Figure 3. Woodrat midden from the central Mojave Desert collected during the Yucca Mountain High-level Nuclear Waste Repository Site characterization program (left), modern woodrat nest (upper right), and woodrat midden sample ready for processing (lower right).

Table 3. Plant microfossil assemblages from central Mojave Desert packrat middens.

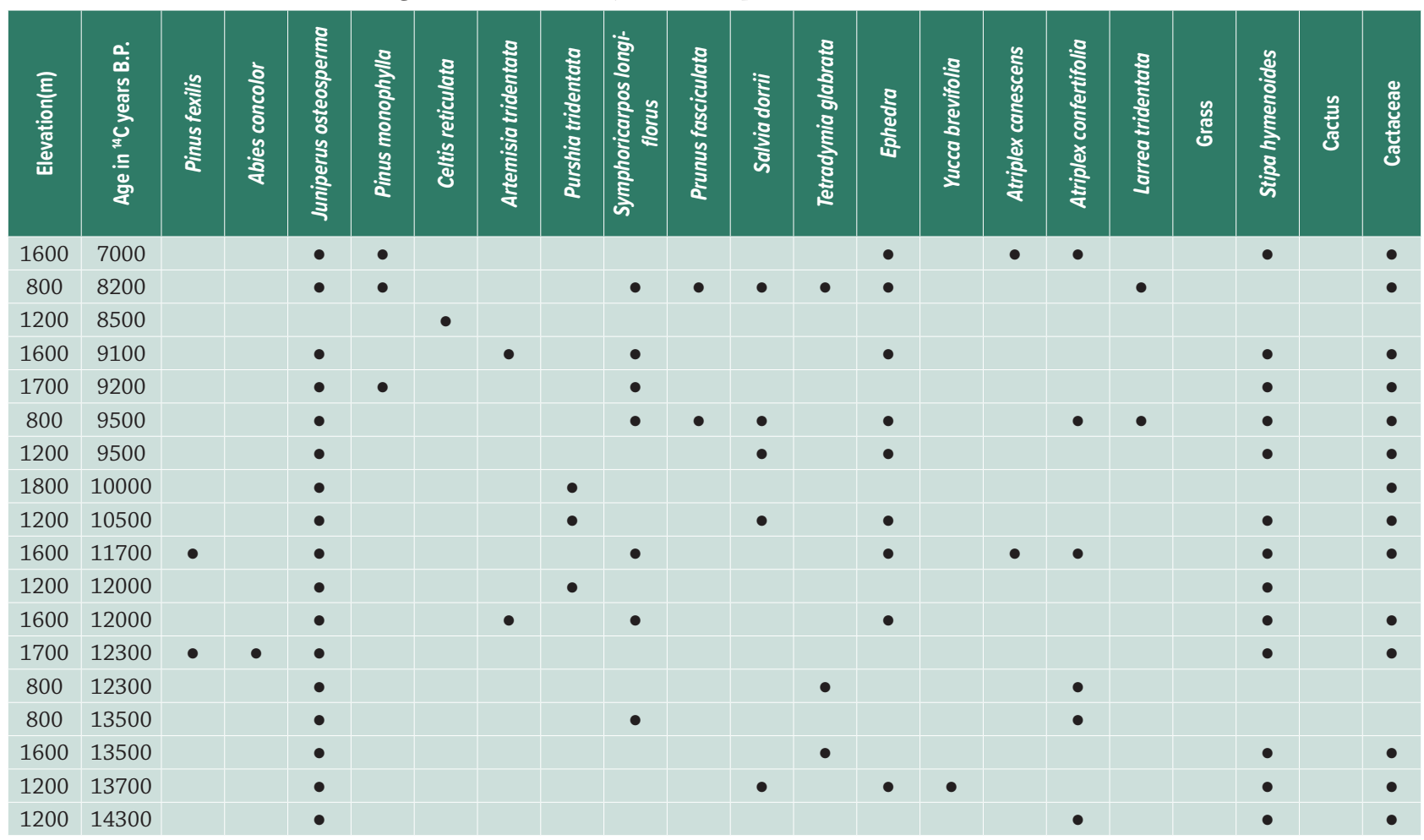




\section{Discussion}

Preservation is clearly an issue with pollen samples from the Cima volcanic field. The pollen counts (Pollen Sum and Total Pollen) indicate that the number of pollen present declines dramatically below $70 \mathrm{~cm}$ (Tab. 4). Calculation of the actual pollen per sample using the Lycopodium spores recovered and the pollen grains counted. indicate that even below the first $20 \mathrm{~cm}$ or so preservation declines dramatically. Pollen type diversity indicates that even though some types are rare, it is clear that preservation is much worse below $70 \mathrm{~cm}$ as many pollen types disappear from the record. The surface textures of most of the pollen grains has been destroyed, or severely degraded, even in the uppermost sample suggesting either bacterial activity, or oxidation. Despite issues with preservation, the number of Lycopodium recovered for statistical purposes were generally sufficient to provide adequate estimates of pollen populations, except for the lowest sample. Lycopodium values for sample six are low, however estimates of its pollen population are probably close to the abundance of pollen in the sample. Creosote bush pollen is not found in this record. Both Ambrosia dumosa (white bursage) and Larrea tridentate (creosote bush) are common within the Cima volcanic field basalt flows today (Figs. 4, 5).

Table 4. Pollen and spore count statistics, and population estimates for the Cima volcanic field samples. Note that the pollen sum (total terrestrial pollen) and pollen total (total terrestrial and aquatic pollen-we did have Cyperaceae and Sedge pollen) decreases rapidly with depth. Also, the total Ambrosia pollen, and total pollen population estimates per sample decreases rapidly with depth as well.

\begin{tabular}{|c|c|c|c|c|c|c|}
\hline Sample Number & Pollen Sum & Total Pollen & Total Spores & Lycopodium Recovered & Mean Ambrosia Population Estimate & Total Pollen Population Estimate \\
\hline CV-1 & 114 & 115 & 0 & 24 & 52651 \\
\hline CV-2 & 40 & 40 & 0 & 90 & 4955 \\
\hline CV-3 & 82 & 82 & 0 & 79 & 11761 \\
\hline CV-4 & 19 & 19 & 3 & 102 & 1821 \\
\hline CV-5 & 6 & 6 & 1 & 58 & 640 \\
\hline CV-6 & 1 & 1 & 0 & 8 & 4645 \\
\hline
\end{tabular}

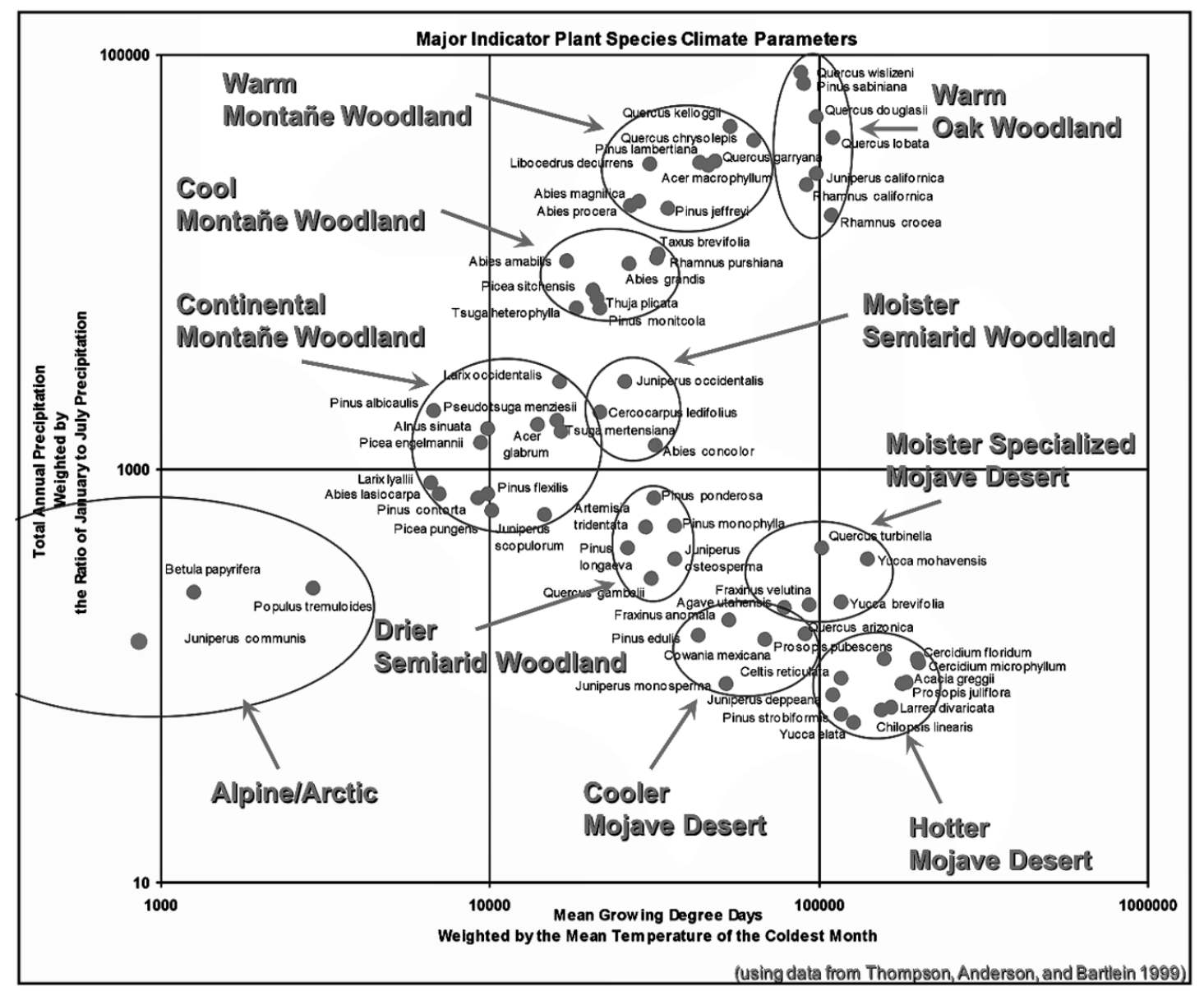

Figure 4. Plant assemblages based upon climate parameters identified in Thompson et al. 1999. The y axis uses precipitation variables, and the $\mathrm{x}$ axis uses temperature variables to establish the climatic clustering of plant species. 


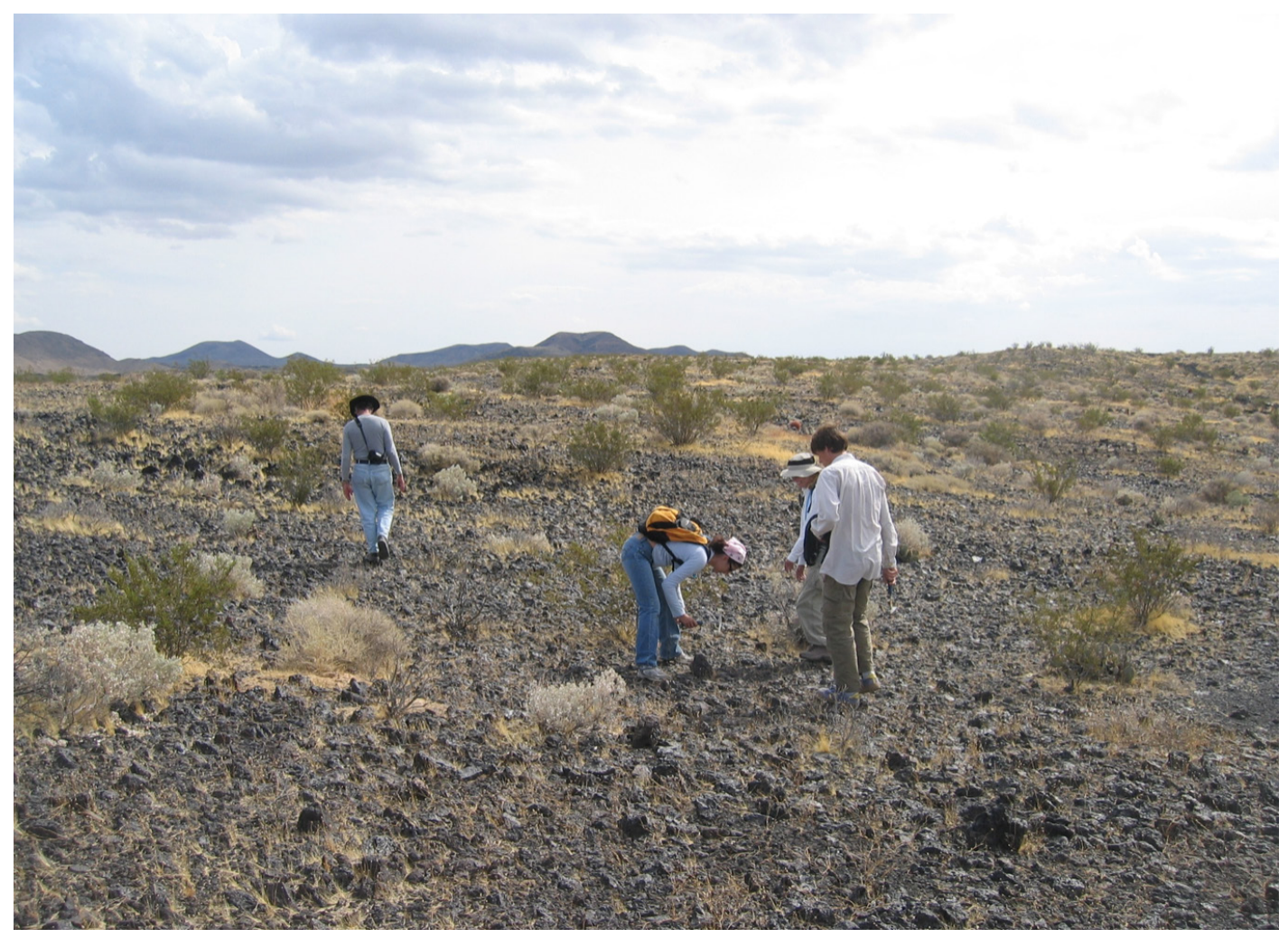

Figure 5. The surface of the distal end (western end) of the Cima volcanic field lava flows. Here a plant community dominated by creosote bush and white bursage is mixed with occasional desert holly (J. McCrea photo).

In our counts, only Ambrosia dumosa pollen appears in the record. This does not mean that Larrea tridentata was not present at the Cima volcanic field, rather the discrepancy may be due to the nature of creosote bush flowers. Larrea tridentata is insect pollinated with several species of native bees being specially adapted to its pollination (Fig. 6). Because creosote bush is insect pollinated, it also produces much less pollen. On the other hand, Ambrosia dumosa is wind pollinated and has no petals so that the wind may blow the pollen directly off the anthers, and flowers are arranged along a stalk that can intercept the pollen in the wind (Fig. 6). In addition, white bursage produces abundant pollen several magnitudes greater than creosote bush, so there is a much greater statistical probability of it appearing in a poorly preserved pollen record. This issue also characterized the pollen record from Lower Pahranagat Lake north northeast of Las Vegas (Wigand 2017). Creosote bush was the dominant plant in the community surrounding Lower Pahranagat Lake, but it rarely appeared in the pollen record. Though creosote bush and white bursage may appear just as abundant on the landscape their presence in the pollen record can be significantly different. Finally, two other common pollen types recovered from the Cima volcanic field samples are Sphaeralcea (globe mallow) and Eriogonum (buckwheat) (Fig. 6). The globe mallow blooms in spring and is quite common throughout the Mojave Desert. Buckwheat is very common throughout the Mojave Desert and blooms in the spring as well and may represent several different species.

The regional woodrat midden record indicates that some components of the Mojave Desert vegetation community arrived during the late Pleistocene (e.g., Yucca brevifolia). Others appear briefly and disappear and reappear again during the early Holocene. This seems to mirror the high variability of the climate during this period. In the MCM climate reconstruction, summer precipitation has several episodes of highly variable precipitation. Both the short frequency and high magnitude of rainfall during these periods is unique when the climate reconstruction for the last 17,000 years is viewed. The spring and fall precipitation pattern generally follow that of summer, but at much reduced magnitudes (Fig. 7). The first period of high magnitude and high frequency summer (and spring and fall) precipitation occurs between 15,000 and 14,000 Cal. years B.P. It is at this time Yucca brevifolia appears at Little Skull Mountain at the southern end of the Nevada Test Site. The second episode occurs between 13,500 and 11,000 Cal. years B.P. and is characterized by a slight increase in shrub species diversity. It is not until 9,500 Cal. years B.P. that the full array of Mojave Desert shrub species becomes common and wide spread at all lower elevations in the woodrat midden record (Tab. 4). After 10,500 Cal. years B.P. the current range of climate conditions became stabilized and Mojave Desert plant species came to characterize the vegetation assemblages of the region. Until 10,500 Cal. years B.P. the 
movement of Mojave Desert plant species into the region may be visualized as waves lapping onto the seashore as the tide rises. Each intrusion of a plant species may have been characterized by species establishment followed by local extinctions as the climate temporarily reverted to less favorable conditions.

\section{Conclusion}

The pollen from the Cima volcanic field reveals a record from at least $\sim 8,300 \mathrm{Cal}$. years B.P. to the present of typical Mojave Desert vegetation. Though preservation is clearly an issue, pollen types offrom plants of the modern Mojave
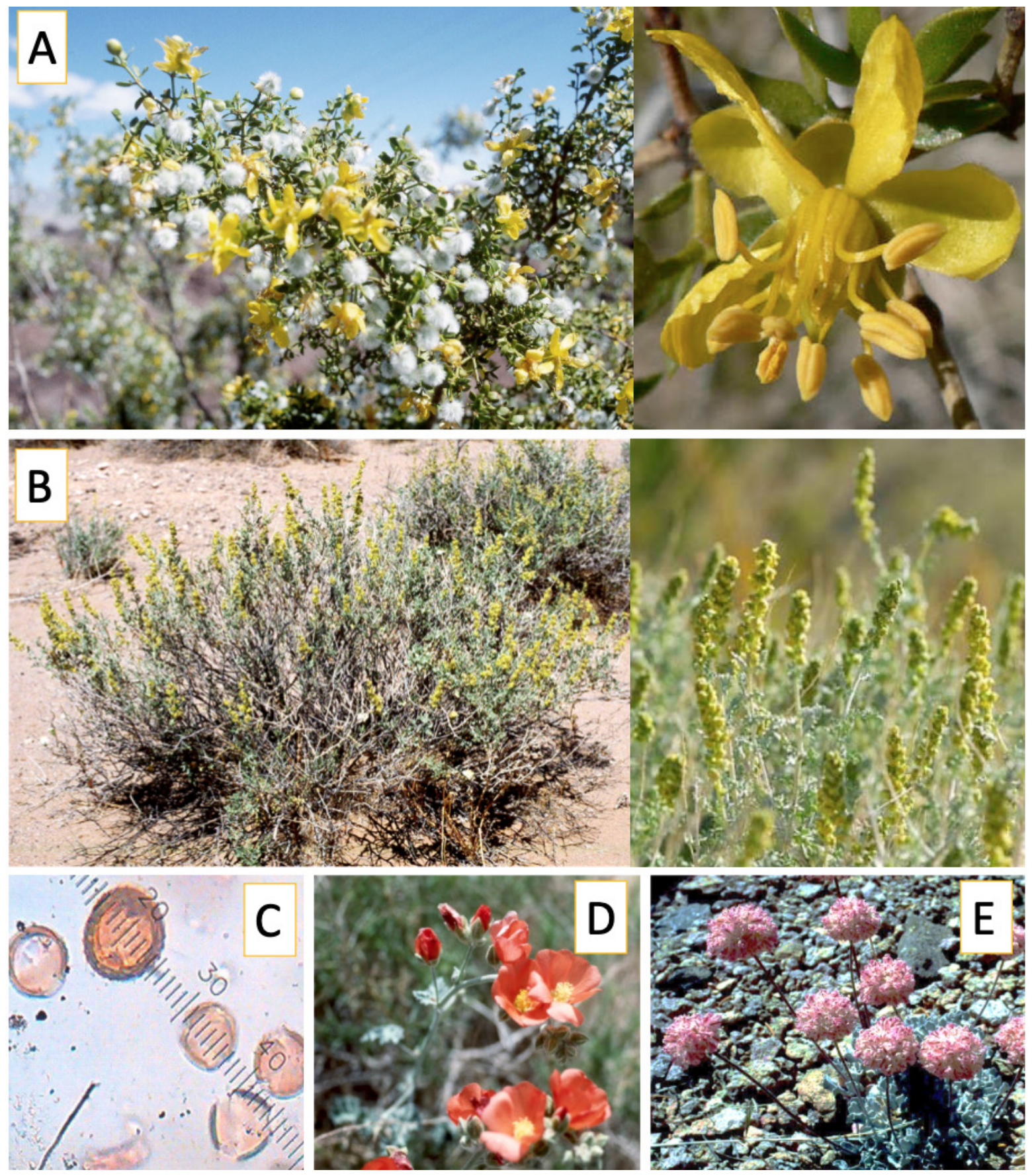

Figure 6. A. Photos of Larrea tridentata illustrating the flower structure and their arrangement on the plant. This is efficient for insect pollination but not wind pollination; B. Photos of Ambrosia dumosa illustrating the structure of the flowers and the efficient flower stalk arrangement for wind pollination; C. Creosote bush (the smaller pollen grain) is a thick-walled pollen grain and should survive some degradation. White bursage is the larger thick-walled pollen grain with rough surface structure. Although creosote bush should be there, its pollination ecology does not provide sufficient opportunities for it to be preserved in the record; D. Globe mallow; E. Buckwheat. 


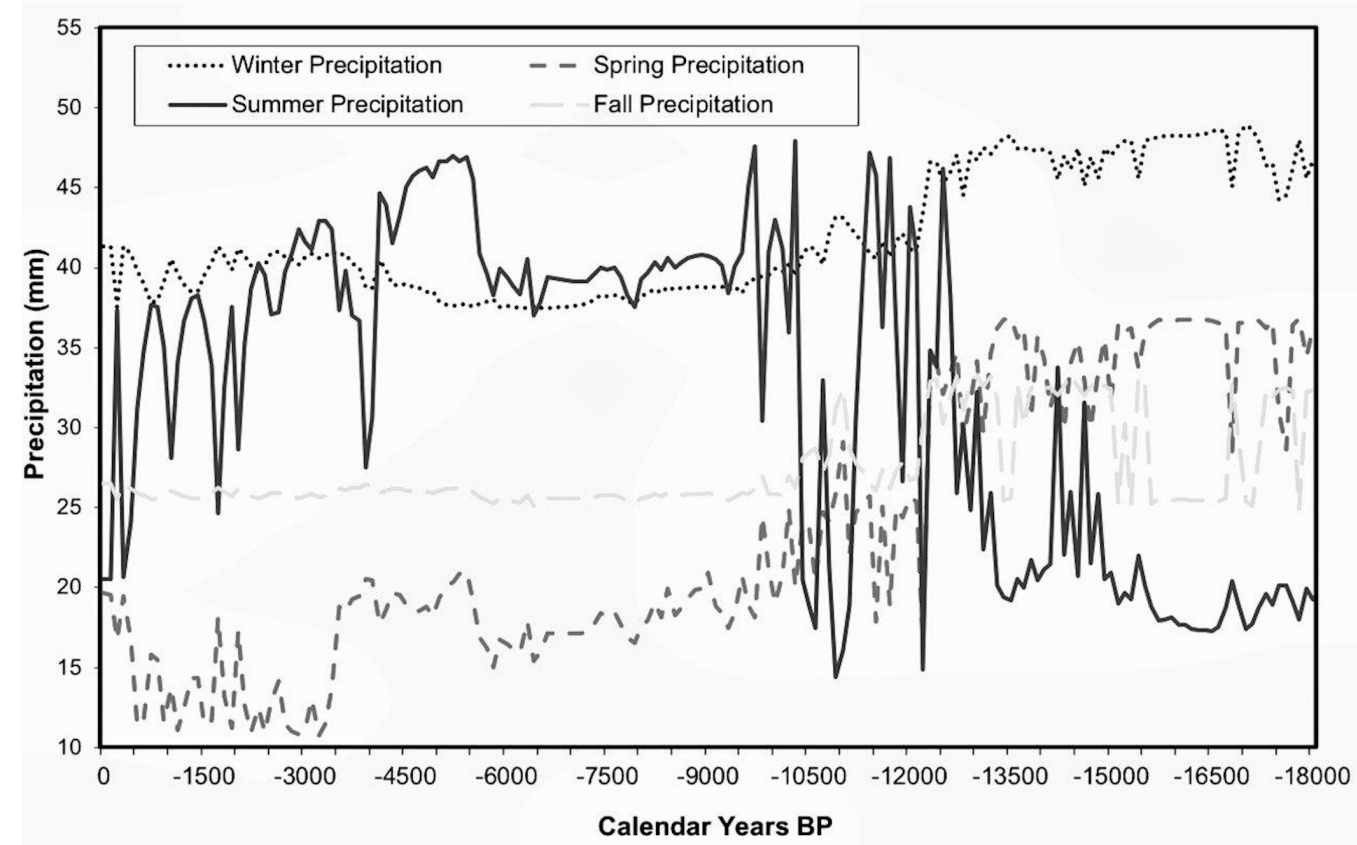

Figure 7. MCM modeled seasonal precipitation for the northeastern Mojave Desert region for the last 15,000 cal. B.P.

Desert are found throughout the record. Although pollen of creosote bush was not present, studies have shown that this is often an artifact of pollen preservation. This record in combination with the woodrat midden record of the area surrounding Yucca Mountain provides evidence for an earlier Holocene establishment of Mojave Desert vegetation community than previously thought. It also indicates that the formation of the Mojave Desert plant community was characterized by intermittent establishments during episodes of favorable climate and retreats and possible local extinctions during less favorable periods of climate. Some species became established as early as 16,000 years ago during the late Pleistocene.

\section{Acknowledgements}

We thank Dr. Marith Reheis for providing the Cima volcanic field samples for analysis. They have provided us with a very nice window at lower elevation into the early formation of the Mojave Desert. Midden samples were processed under funding provided by both the State of Nevada and the DOE for site characterization of the Yucca Mountain High-Level Nuclear Waste Storage Facility.

\section{References}

Brown WJ, Wells SG, Enzel Y, Anderson LD, McFadden LD. 1990. The late Quaternary history of pluvial Lake Mojave-Silver Lake and Soda Lake basins, California. In: Reynolds RE, Wells SG, Brady RH. (eds.) At the end of the Mojave: Quaternary studies in the Eastern Mojave Desert. Redlands, San Bernadino County Museum Association. p. 55-72.

Bryson RA, Bryson RU. 2000. Site-specific high-resolution models of the monsoon for Africa and Asia. Global and Planetary Change 26: 77-84.
Cole KL.1985. Past rates of change, species richness, and a model of vegetational inertia in the Grand Canyon, Arizona. American Naturalist 125: 289-303.

Dohrenwend JC, McFadden LD, Turrin BD, Wells SG. 1984. K-Ar dating of the Cima volcanic field, eastern Mojave Desert, California: Late Cenozoic volcanic history and landscape evolution. Geology 12:163-167.

Dohrenwend JC, Wells SG, Turrin BD.1986. Degradation of Quaternary cinder cones in the Cima volcanic field, Mojave Desert, California. Geological Society of America Bulletin 97: 421-427.

Harvey AM, Wigand PE, Wells SG. 1999. Response of alluvial fan systems to the late Pleistocene to Holocene climatic transition: contrasts between the margins of pluvial Lakes Lahontan and Mojave, Nevada and California, U.S.A. Catena 36: 255-281.

Koehler PA, Anderson SR, Spaulding GW. 2005. Development of vegetation in the Central Mojave Desert of California during the late Quaternary. Palaeogeography, Palaeoclimatology, Palaeoecology 215: 297-311.

Langbein WB, Schumm SA. 1958. Yield of sediment in relation to mean annual precipitation. Eos, Transactions American Geophysical Union 39: 1076-1084.

McKinney D. 2018. Climate of the Mojave. https://sciencing.com/climatemojave-4033.html.

Quade J, Forester RM, Pratt WL, Carter C. 1998. Black mats, spring-fed streams, and late-glacial-age recharge in the southern Great Basin. Quaternary Research 49: 129-148.

Reimer PJ, Bard E, Bayliss A, et al. 2013. IntCal13 and Marine13 Radiocarbon Age Calibration Curves 0-50,000 Years cal BP. Radiocarbon 55:1869-1887.

Spaulding WG. 1985. Vegetation and climates of the last 45,00 Years in the vicinity of the Nevada Test Site, South-Central Nevada. U.S.G.S. Professional Paper 1329. Washington, United States Government Printing Office.

Thompson RS, Anderson HK, Bartlein PJ. 1999. Atlas of Relations Between Climatic Parameters and Distributions of Important Trees and Shrubs in North America. Introduction and Conifers U.S. Geological Survey Professional Paper 1650-A: 1-698

Turrin BD, Dohrenwend JC, Drake RE, Curtis GH. 1985. K-Ar ages from the Cima volcanic field, eastern Mojave Desert, California. Isochron West 44: 9-16.

Wigand PE. 1987. Diamond Pond, Harney County, Oregon: Vegetation history and water table in the eastern Oregon desert. Great Basin Naturalist 47:427-458. 
Wigand PE. 2003. Middle to late Holocene climate and vegetation dynamics. In: Rosenthal JS, Eerkens J. (eds.) Research issues revisited. The Archaeology of Coso Basin: Test Excavations at 28 Sites Located in the North Ranges Complex, NAWS, China Lake. Davis, Far Western Anthropological Research Group.

Wigand PE. 2017. Southwestern North America. In: Elias SA. (ed.) The encyclopedia of quaternary science, reference module in earth systems and environmental science. 3rd. edn. Amsterdam, Elsevier. p. 1-33.

Wigand PE, Rhode D. 2002. Great basin vegetation history and aquatic systems: The Last 150,000 years 309-367. In: Hershler R, Madsen DB,
Currey DR. (eds.) Great basin aquatic systems history. Smithsonian Contributions to Earth Sciences 33. Washington, Smithsonian Institution Press. p. 309-367.

Wilshire HG, Frisken JG, Jachens RC, Prose E, Rumsey CM, McMahan A. 1987. Mineral resources of the cinder cones widerness study area, San Bernadino country, California, U.S. Geological Society of America Bulletin 1712: 1-13.

Wood YA, Graham RC, Well SG. 2005. Surface control of desert pavement pedologic process and landscape function, Cima volcanic field, Mojave Desert, California. Catena 59: 205-230. 